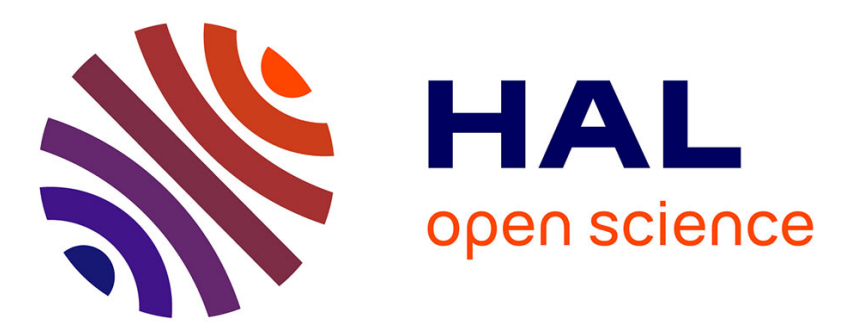

\title{
Endocannabinoid functions controlling neuronal specification during brain development
}

Tibor Harkany, Erik Keimpema, Klaudia Barabás, Jan Mulder

\section{To cite this version:}

Tibor Harkany, Erik Keimpema, Klaudia Barabás, Jan Mulder. Endocannabinoid functions controlling neuronal specification during brain development. Molecular and Cellular Endocrinology, 2008, 286 (1-2), 10.1016/j.mce.2008.02.011 . hal-00532002

\section{HAL Id: hal-00532002 https://hal.science/hal-00532002}

Submitted on 4 Nov 2010

HAL is a multi-disciplinary open access archive for the deposit and dissemination of scientific research documents, whether they are published or not. The documents may come from teaching and research institutions in France or abroad, or from public or private research centers.
L'archive ouverte pluridisciplinaire HAL, est destinée au dépôt et à la diffusion de documents scientifiques de niveau recherche, publiés ou non, émanant des établissements d'enseignement et de recherche français ou étrangers, des laboratoires publics ou privés. 


\section{Accepted Manuscript}

Title: Endocannabinoid functions controlling neuronal specification during brain development

Authors: Tibor Harkany, Erik Keimpema, Klaudia Barabás, Jan Mulder

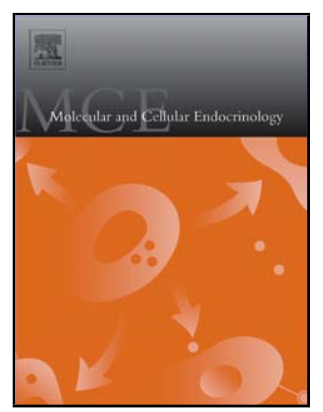

PII:

S0303-7207(08)00088-9

DOI: doi:10.1016/j.mce.2008.02.011

Reference: MCE 6825

To appear in: Molecular and Cellular Endocrinology

Received date: 21-12-2007

Revised date: 19-2-2008

Accepted date: $19-2-2008$

Please cite this article as: Harkany, T., Keimpema, E., Barabás, K., Mulder, J., Endocannabinoid functions controlling neuronal specification during brain development, Molecular and Cellular Endocrinology (2007), doi:10.1016/j.mce.2008.02.011

This is a PDF file of an unedited manuscript that has been accepted for publication. As a service to our customers we are providing this early version of the manuscript. The manuscript will undergo copyediting, typesetting, and review of the resulting proof before it is published in its final form. Please note that during the production process errors may be discovered which could affect the content, and all legal disclaimers that apply to the journal pertain. 


\title{
Endocannabinoid functions controlling neuronal specification during brain development
}

\author{
Tibor Harkany'1,2,@, Erik Keimpema1, Klaudia Barabás \& Jan Mulder ${ }^{1}$ \\ 1Institute of Medical Sciences, School of Medical Sciences, University of Aberdeen, Aberdeen, AB25 2ZD, \\ Scotland, United Kingdom and 2Division of Molecular Neurobiology, Department of Medical Biochemistry \& \\ Biophysics, Karolinska Institutet, SE-17177 Stockholm, Sweden.
}

@Corresponding author: Tibor Harkany, Ph.D.; Phone: +44 $1224555904^{1}$ or +46 8524 878352; Fax: +44 1224 $555915^{1}$ or +46 8341 9602; e-mail: t.harkany@abdn.ac.uk or Tibor.Harkany@ki.se

\begin{abstract}
Endocannabinoids (eCBs) regulate a broad range of physiological functions in the postnatal brain and are implicated in the neuropathogenesis of psychiatric and metabolic diseases. Accumulating evidence indicates that eCB signaling also serves key functions during neurodevelopment; and is inherently involved in the control of neurogenesis, neural progenitor proliferation, lineage segregation, and the migration and phenotypic specification of immature neurons. Recent advances in developmental biology define fundamental eCB-driven cellular mechanisms that also contribute to our understanding of the molecular substrates of prenatal drug, in particular cannabis, actions. Here, we summarize known organizing principles of eCB signaling systems in the developing telencephalon, and outline the sequence of decision points and underlying signaling pathways upon $\mathrm{CB}_{1}$ cannabinoid receptor activation that contribute to neuronal diversification in the developing brain. Finally, we discuss how these novel principles affect the formation of complex neuronal networks.
\end{abstract}

Running title: Endocannabinoids in the developing brain.

Key words: brain development | embryo | interneuron | lineage | pyramidal cell | synapse 


\section{Contents}

1. Introduction

2. Developmental specification of endocannabinoid signaling

3. Differential signaling through $C B_{1}$ cannabinoid receptors underscores neuronal specification

4. Endocannabinoids regulate neuronal commitment and cell migration

5. $\quad C B_{1}$ cannabinoid receptors are targeted to developing axons

6. Endocannabinoid shape neuronal connectivity

7. Conclusions

8. Acknowledgements

9. References

\section{Introduction}

Our knowledge of the structural substrates, spatial composition, and functional significance of endocannabinoid (eCB) signaling has recently undergone rapid expansion because of the continued identification of novel eCBs and related lipid mediators, bioactive intermediates, metabolic enzymes, cannabinoid receptors, and contextdependent recruitment of signaling pathways downstream from cannabinoid receptors (Brown, 2007; Daigle et al., 2008; Egertova et al., 2007; Lauckner et al., 2008; Mackie et al., 2006; Wei et al., 2006). In the adult CNS, eCBmediated retrograde synaptic signaling implies the selective recruitment of $C_{1}$ cannabinoid receptors $\left(C_{1} R s\right)$ to both inhibitory and excitatory presynaptic terminals thus allowing sensing of on-demand eCB release from postsynaptic neurons (Lutz, 2004). The activity-dependent release of eCBs thereby controls synaptic plasticity in many brain regions including the neocortex, hippocampus, cerebellum, and basal ganglia (Kreitzer et al., 2001; Matyas et al., 2008; Ohno-Shosaku et al., 2002; Wilson et al., 2001b; Wilson et al., 2001a). Although the molecular machinery underscoring retrograde $\mathrm{eCB}$ release in the postnatal brain is well-established (Piomelli, 2003), our understanding of $\mathrm{eCB}$ functions during neurodevelopment has just begun to unfold. Contemporary evidence indicates that in the developing central nervous system (CNS) anandamide (AEA) and 2arachidonoylglycerol (2-AG), the main known eCBs, and $\Delta^{9}$-tetrahydrocannabinol ( $\left.\Delta^{9}-\mathrm{THC}\right)$, the major psychoactive component in cannabis (Cannabis spp.), target cannabinoid receptors differentially on neural progenitors (Arevalo-Martin et al., 2007; Molina-Holgado et al., 2007), immature neurons (Berghuis et al., 2005; Berghuis et al., 2007; Mulder et al., 2008; Watson et al., 2008), and glia (Aguado et al., 2006; Molina-Holgado et al., 2002) (Fig. 1). Functional studies have demonstrated that this family of lipid mediators is involved in the regulation of neural progenitor proliferation and lineage commitment (Galve-Roperh et al., 2006; Mulder et al., 2008); instructs the migration and differentiation of neuronal precursors (Berghuis et al., 2005; Berghuis et al., 2007; Harkany et al., 2007; Mulder et al., 2008); and affects the onset of synaptic communication in neonatal 
neuronal networks (Berghuis et al., 2007; Bernard et al., 2005; Mereu et al., 2003). While the concepts described herein are primarily derived from experimental data on mammalian expression systems (see also: (Watson et al., 2008)) with well-accepted ligands, metabolic enzymes, and $\mathrm{CB}_{1}$ Rs in neurons, the recent expansion of metabolic pathways critical for eCB synthesis and degradation (Egertova et al., 2007; Liu et al., 2006; Mulder et al., 2006; Simon et al., 2006; Wei et al., 2006), and the identification of novel cannabinoid receptors, particularly the orphan G protein-coupled receptor GPR55 (Baker et al., 2006; Johns et al., 2007; Lauckner et al., 2008; Oka et al., 2007; Ryberg et al., 2007) suggest a future leap in our understanding of eCB functions during brain development.

\section{Developmental specification of endocannabinoid signaling}

The molecular organization of $\mathrm{eCB}$ metabolism and respective receptor systems during brain development is such that eCBs may effectively tune the cellular specification programs of both neural progenitors and lineagecommitted neuronal precursors (Harkany et al., 2007). At present, a comprehensive neuroanatomical analysis of eCB signaling components during brain development is lacking; which is primarily due to our restricted knowledge of key enzymes regulating eCB bioavailability, and of eCB-sensing receptors. The parallel, and often compensatory metabolic pathways controlling eCB levels, and the promiscuity of eCB actions on a broad range of developmentally-regulated receptors and ion channels (Matias et al., 2006; Piomelli, 2003; van der Stelt et al., 2005) suggest divergent roles of eCB signaling in the developing brain.

Endocannabinoid (AEA, 2-AG) concentrations vary substantially throughout brain development (Berrendero et al., 1999; Fernandez-Ruiz et al., 2000): low AEA levels are present in the brain at mid-gestation with gradually increasing AEA concentrations ( $3-6 \mathrm{pmol} / \mathrm{g}$ tissue) throughout the perinatal period until adult concentrations are reached (Berrendero et al., 1999). In contrast, prenatal 2-AG concentrations (2 - $8 \mathrm{nmol} / \mathrm{g}$ tissue) are similar to those in young and adult rodent brains (Berrendero et al., 1999; Fernandez-Ruiz et al., 2000). Although the above data are conclusive on total levels of eCBs in nervous tissues at distinct stages of neurodevelopment, functional implication(s) of these findings are rather ambiguous. This is primarily due to the diverse metabolic roles eCB ligands fulfill, their probable direct interactions tuning neuronal responsiveness (Maccarrone et al., 2008), their receptor promiscuity, and variations in their effective concentrations at diverse cannabinoid-sensing receptors relevant to initiating downstream signaling in vivo.

Establishment of temporally and spatially-coordinated $\mathrm{eCB}$ release requires fine-tuned expression of metabolic enzymes. Two isoforms $(\alpha$ and $\beta$ ) of $s n$-1-diacylglycerol lipase (DAGL $\alpha / \beta)$ are the prime 2-AG synthetic enzymes, and are generally accepted to generate physiologically relevant concentrations of 2-AG both in heterologous expression systems and in vivo (Bisogno et al., 2003). These initial studies suggest a spatial association between the sites of $D A G L a / \beta$ and $C_{1} B_{1} R$ expression in the developing brain at mid-gestation, with dominant subcellular localization in axons populating long-range subcortical and cerebellar projection tracts (Bisogno et al., 2003). DAGL localization to elongating corticothalamic and intercallosal axons negatively correlates with morphological axon differentiation (Mulder et al., 2008), and leads to a striking activity-dependent developmental switch, with dendrites of postnatal neurons being preferential sites of eCB synthesis and release 
in mature neurons (Bisogno et al., 2003; Katona et al., 2006; Uchigashima et al., 2007). A series of candidate enzymes with considerable AEA biosynthetic activity has recently been identified, including $N$-acylphosphatidylethanolamine-selective phospholipase D (NAPE-PLD) (Egertova et al., 2007; Morishita et al., 2005; Okamoto et al., 2007; Ueda et al., 2005), $\alpha / \beta$-hydrolase 4, a lyso-NAPE lipase to form $\mathrm{N}$-acyl ethanolamines (Simon et al., 2006), and PTPN22, a phosphatase cleaving NAPE-derived phospho-AEA to yield AEA (Liu et al., 2006). Recent data (Berghuis et al., 2007) indicate NAPE-PLD localization already in neonatal mouse brain, with non-detectable enzyme levels during earlier developmental periods. This finding supports a role for 2-AG as primary $\mathrm{CCB}$ during neurodevelopment; however, possible mechanisms of activity-dependent $\mathrm{AEA}$ release, and receptor-level regulatory interactions between AEA and 2-AG signaling remain to be established.

Monoacylglycerol lipases 1/2 (MGLs) (Dinh et al., 2002; Muccioli et al., 2007) and fatty-acid amide hydrolases 1/2 (FAAH1/2) (Cravatt et al., 1996; Wei et al., 2006) have been established as major catabolic enzymes degrading 2-AG and AEA, respectively. Notably, however, the substrate-specificity and catabolic activity of FAAH may exhibit significant changes under specific conditions thus affecting not only AEA but also 2-AG levels (Harkany et al., 2007; Maione et al., 2006). Whereas the cellular distribution of MGL1/2 during brain development is as yet unknown, FAAH has been detected in radial glia during late gestation and throughout the neonatal period (Aguado et al., 2006; Harkany et al., 2007). In neurons, however, FAAH expression may be either transient or permanent: hippocampal interneurons undergoing intralaminar migration only transiently express FAAH in vitro (Berghuis et al., 2005) or during the first postnatal week in vivo (Morozov et al., 2004) suggesting the differential involvement of AEA signaling to interneuron specification. In sum, these data show that eCB levels are dynamically regulated during brain development.

Precise expression patterns are available for the $C_{1} R$ in the developing $C N S . C B_{1}$ Rs have been detected as early as day 11 of gestation in the murine CNS with peak mRNA levels in cortical pyramidal cells by embryonic days 14-15 (Mulder et al., 2008). In contrast, $\mathrm{CB}_{1} \mathrm{R}$ expression in interneurons becomes only detectable during late gestation/birth with persistently high expression levels postnatally (Berghuis et al., 2007; Harkany et al., 2007). Accordingly, $C B_{1} R$ levels are undetectable in post-mitotic interneuron progenitors at their extracortical origins (ganglionic eminences) or during tangential migration (Berghuis et al., 2007). Similar $\mathrm{CB}_{1} \mathrm{R} m \mathrm{~m} N A$ expression patterns have been reported during human pre- and postnatal CNS development by in situ hybridization (Wang et al., 2003). Pharmacological studies indicate the functionality of $\mathrm{CB}_{1} \mathrm{Rs}$ in embryonic neural tissues since WIN55212-2, a cannabinoid receptor agonist, significantly stimulated ${ }^{35}$ S] GTPYS binding in both rodent and human brains (Mato et al., 2003; Wang et al., 2003).

Is the $\mathrm{CB}_{1} \mathrm{R}$ the only cannabinoid-sensing receptor expressed in the developing brain? In vitro data suggest that both stem cell differentiation and glial specification are affected by pharmacological modulation of $\mathrm{CB}_{2} \mathrm{Rs}$, and glial cells may simultaneously express both $\mathrm{CB}_{1} \mathrm{Rs}$ and $\mathrm{CB}_{2} \mathrm{Rs}$ (Arevalo-Martin et al., 2007; Molina-Holgado et al., 2007). However, neither the spatial nor the temporal embryonic expression of this receptor class is known. Similarly, multiple orphan receptors, including GPR35, GPR55, and GPR119 may have expression loci in the mammalian CNS (Brown, 2007; Lauckner et al., 2008; Sawzdargo et al., 1999) and thus, could affect particular cellular processes during neurodevelopment. This notion is reinforced by the robust effects of GPR55 activation 
on extracellular signal-regulated kinase (Erk1/2) pathways (Oka et al., 2007), on intracellular $\mathrm{Ca}^{2+}$ transients (Abe et al., 2005; Lauckner et al., 2008), and on the activity of small GTPases (RhoA, cdc42, and Rac) (Lauckner et al., 2008; Ryberg et al., 2007). Considering that these signal transduction mechanisms are pivotal for neuronal specification, axonal growth, and growth cone steering decisions mediated by eCBs (Berghuis et al., 2007), a key developmental role for GPR55 can be postulated. It is also important to note that coincident eCB actions on multiple receptor systems (e.g., CB1R, GPR55, transient receptor vanilloid potential 1 (TRPV1), and others), and their differential coupling to second messenger cascades may further increase the complexity of developmental eCB signaling. Overall, neuroanatomical findings furnish the concept that the eCB system is expressed and positioned during CNS development such that its activity can optimally control fundamental developmental processes (Fig. 1).

\section{Differential signaling through $\mathrm{CB}_{1}$ cannabinoid receptors underscores neuronal specification}

$\mathrm{CB}_{1}$ Rs belong to the superfamily of 7 transmembrane domain-containing $\mathrm{G}$ protein-coupled receptors (GPCRs), and exhibit $44 \%$ overall homology to the $\mathrm{CB}_{2} \mathrm{R}$ (Munro et al., 1993). Recent advances in receptor biology argue that receptor multimers function as key signaling units (Devi, 2000), and accordingly, $\mathrm{CB}_{1}$ Rs likely signal as homodimers (Wager-Miller et al., 2002). Receptor dimerization is a critical molecular phenomenon during neurodevelopment, as the diversity of interacting receptors, such as those of neurotrophins and growth factors (Berghuis et al., 2005; Williams et al., 2003), recruited to the $\mathrm{CB}_{1} \mathrm{R}$ can further diversify and refine developmental eCB actions. $\mathrm{CB}_{1}$ Rs preferentially couple to $\mathrm{G}_{\text {i。o }}$ proteins. Post-translational modification (splice variants) (Ryberg et al., 2005), specific ligands, receptor interactions (Harkany et al., 2007), interacting proteins (Niehaus et al., 2007), or preferential recruitment of particular downstream effectors (Galve-Roperh et al., 2006) however may shift $C_{1} R$ signaling such that $G_{s}\left(G_{q / 11}\right)$ protein coupling occurs (Lauckner et al., 2005). Irrespective of the particular $G_{\beta \gamma}$ protein complex (lyengar, 2005), $C_{1} R$ s are critical for the regulation of the activity of, e.g., ion channels, neurotransmitter transporters, metabolic enzymes, and cytoskeletal integrity (Berghuis et al., 2007; Derkinderen et al., 1996; Derkinderen et al., 2003; He et al., 2005; Rios et al., 2006; van der Stelt et al., 2005). The 'on-demand' recruitment of second messengers to the $\mathrm{CB}_{1} \mathrm{R}$, e.g., the Src/Stat3 (He et al., 2005; Jordan et al., 2005), Erk1/2 (Berghuis et al., 2007; Derkinderen et al., 2003; Galve-Roperh et al., 2000; Rueda et al., 2002), and PI3K/Akt pathways (Molina-Holgado et al., 2002), and the modulation of sphingolipid-derived signaling mediators and cell death pathways (Guzman, 2003) enhance the potential of the $C_{1} R$ to dynamically regulate the spatial and temporal coordination of e.g., neural progenitor proliferation and fate decision, migration, and lineage specification (Galve-Roperh et al., 2007; Harkany et al., 2007). In sum, cross-talk between the eCB and other signaling systems can influence neurodevelopment. The interaction of alternative eCB signaling pathways, many of them as yet only partially known, converging on the $\mathrm{CB}_{1} \mathrm{R}$ provides a unifying mechanistic perspective explaining diverse developmental actions of eCB on various neuron populations. 


\section{Endocannabinoids regulate neuronal commitment and cell migration}

During brain development, the establishment of $\mathrm{ECB}$ signaling networks coincides with the expansion of neural progenies and their engagement in establishing neuronal diversity (Galve-Roperh et al., 2006). Functional eCB signaling in neurogenic proliferative zones, represented by $D A G L$ and $C B_{1} R / C B_{2} R$ expression (Aguado et al., 2005; Molina-Holgado et al., 2007; Mulder et al., 2008), suggests that eCBs could provide extracellular cues instructing the cellular program of neural progenitors such that they generate appropriate contingents of cell lineages required to build the developing brain. A fine-tuned balance between progenitor cell proliferation and programmed death guarantees the generation of adequate quantities of neural cells during brain development. It is evident that eCBs regulate neural progenitor commitment and survival (Aguado et al., 2006; Guzman et al., 2001; Guzman et al., 2002; Mulder et al., 2008). Neural progenitors possess a functional eCB signaling loop: the capacity to synthesize eCBs, functional $\mathrm{CB}_{1} \mathrm{Rs}$, and catabolic enzyme(s) (Aguado et al., 2005). $\mathrm{CB}_{1} \mathrm{R}$ activation is sufficient for progenitor proliferation to occur (Aguado et al., 2006): whilst these actions are lacking in cnr1cells, they become significantly increased in faah ${ }^{-1}$ ones. The eCB system also plays a role in regulating the primary fate decision point of neural progenitors by modulating whether neural precursors commit to generate neurons or glia. Consequently, $\mathrm{CB}_{1} \mathrm{R}$ activation on neural progenitors promotes their differentiation into glial cells (Aguado et al., 2006). In contrast, both pharmacological treatments (Rueda et al., 2002), and eCBs decrease neurogenesis, and inhibit the expression of selective markers of early and terminally-differentiated neurons in vitro. Alternatively, SR141716, a selective $\mathrm{CB}_{1} \mathrm{R}$ antagonist, increases neuronal differentiation of neural progenitors (Jin et al., 2004; Rueda et al., 2002). Collectively, these studies suggest the existence of an eCB tone actively modulating neural progenitor differentiation through the $\mathrm{CB}_{1} \mathrm{R}$ receptor in the developing brain .

The eCB/phytocannabinoid-induced switch that commits neural progenitors to gliogenesis at the expense of neurogenesis clearly poses the question whether eCB effects also impinge on neuronal migration, and on the acquiring of cellular (neurochemical/morphological) identity during terminal neuronal differentiation. Recent evidence indicates that eCBs modulate, through cell type-specific receptor systems and downstream signaling mechanisms, the chemotaxis of various cell types, including glial cells (Walter et al., 2003), neurons (Berghuis et al., 2005), immune cells (Kurihara et al., 2006; McHugh et al., 2007; Miller et al., 2007), smooth muscle cells (Rajesh et al., 2007), cancer cells (Ghosh et al., 2006; Preet et al., 2007) and HEK293 cells (Song et al., 2000). It is important to note that eCBs often interact with other signaling systems, including neurotrophins (Berghuis et al., 2005), growth factors (Preet et al., 2007), and inflammatory cytokines (Rajesh et al., 2007) to induce cell migration. With regards to brain development, experimental evidence indicates that both eCBs and $C B_{1} R$ agonists induce the migration of late-gestational GABAergic interneurons known to undergo long-distance migration to reach their final positions in the developing cerebrum (Berghuis et al., 2005). The finding that eCBs simultaneously inhibit the morphogenesis of GABAergic interneurons outline a complex, yet physiologically ideal signaling mechanism whereby eCBs control neuronal maturity (axonal/dendritic complexity) such that it is most compatible with particular stages of cell differentiation. In vivo support for $\mathrm{CB}_{1} \mathrm{R}$-mediated chemotaxis is provided by the fact that prenatal $\Delta^{9}$-THC increases the density of cholecystokinin-expressing interneurons in the neonatal rat hippocampus (Berghuis et al., 2005), a finding compatible with in vitro data on eCB-induced interneuron 
mobility. Overall, these data suggest that eCBs are instructive signals for both neuronal and glial cell migration and thus contribute to generating neuronal diversity in particular brain regions.

\section{5. $\mathrm{CB}_{1}$ cannabinoid receptors are targeted to developing axons}

The subcellular domains where $\mathrm{CB}_{1} \mathrm{Rs}$ are momentarily accessible to their ligands define the physiological functions eCB signaling subserves whilst regulating neuronal differentiation. It has recently been demonstrated that domain-specific endocytosis, a key mechanism limiting the surface expression of a range of axonal proteins (Sampo et al., 2003; Wisco et al., 2003), determines the cell-surface availability of $\mathrm{CB}_{1}$ Rs in neurons (Leterrier et al., 2006; McDonald et al., 2007a): $\mathrm{CB}_{1}$ Rs on the somatodendritic surface are internalized more rapidly than those in the axonal plasma membrane leading to a net receptor accumulation in the axon. Studies in numerous cellular models (Leterrier et al., 2004; Leterrier et al., 2006; McDonald et al., 2007a) have indicated that $C_{1} B_{1}$ s undergo constitutive endocytosis and recycling, leading to a pronounced intracellular pool of receptors at steady state. Inhibition of $\mathrm{CB}_{1} \mathrm{R}$ endocytosis, using pharmacological blockade or overexpression of dominant-negative dynamin-1, dynamin-2, eps15, or rab5 mutants, reveals a robust change in the cell surface distribution of $\mathrm{CB}_{1} \mathrm{Rs}$ from the axon to a non-polarized state with pronounced somatodendritic plasma-membrane expression (Leterrier et al., 2006; McDonald et al., 2007a). It is also likely that transcytotic delivery of $\mathrm{CB}_{1} \mathrm{R}_{\mathrm{s}}$ to the axonal plasma membrane from the somatodendritic cell-surface contributes to the generation of $\mathrm{CB}_{1} \mathrm{R}$ cell-surface polarity and this may act as a salvage pathway for somatodendritc receptors. The precise mechanisms underlying preferential endocytosis of $\mathrm{CB}_{1} \mathrm{Rs}$ within the somatodendritic compartment of neurons are yet unclear. The selective recruitment of specific anchoring proteins with a capacity to bind $\mathrm{CB}_{1} \mathrm{Rs}$ in axons together with subcellular differences in receptor densities (Rimmerman et al., 2008) and in the molecular composition of the internalization machinery, and adaptor complexes (Niehaus et al., 2007; Seong et al., 2005) may underscore prolonged stabilization of $\mathrm{CB}_{1}$ Rs within axonal plasma membranes. It is, however, of major importance to define whether $\mathrm{CB}_{1} \mathrm{R}$ availability in various subcellular compartments is regulated by ligand availability or by constitutive receptor activity and trafficking; when $\mathrm{eCB}$ availability does not limit the recruitment of $G$ proteins and downstream signaling. The concept that constitutive $\mathrm{CB}_{1} \mathrm{R}$ activity contributes to eCB signaling was initially supported by several lines of studies: fluorescent $\mathrm{CB}_{1} \mathrm{R}$ chimeras display high levels of constitutive endocytosis, leading to a marked intracellular localization at steady state, in HEK293 cells (D'Antona et al., 2006; Ellis et al., 2006; Leterrier et al., 2006), and exposure to $C B_{1} R$ antagonists enhances cell-surface $C B_{1} R$ expression (D'Antona et al., 2006; Leterrier et al., 2004; Leterrier et al., 2006; Rinaldi-Carmona et al., 1998), thought to reflect inhibition of constitutive endocytosis. However, work from the Irving laboratory (Coutts et al., 2001; McDonald et al., 2007a; McDonald et al., 2007b) argues that $\mathrm{CB}_{1} \mathrm{R}$ antagonists do not up-regulate cell surface targeting of wild-type $\mathrm{CB}_{1} \mathrm{Rs}$ in axons of hippocampal neurons. A significant shortcoming of earlier studies is that data on eCB levels were lacking and thus, the ability of cells to maintain an 'eCB tone' by producing endogenous ligands themselves (Turu et al., 2007) or through the cell culture media (e.g., serum components) (Stoddart et al., 2007) has not been excluded. Therefore, the persistent availability of low eCB levels may, in virtually all cellular systems, control basal $\mathrm{CB}_{1} \mathrm{R}$ trafficking and cell-surface availability. Data from Turu and colleagues (Turu et al., 
2007) support this hypothesis by showing that 2-AG release may underlie basal $C_{1} R$ activity neuronal and nonneuronal cells thus stimulating $C_{1} R$ endocytosis. Further evidence on $C_{1} R$ axonal targeting independent of constitutive receptor activity is derived from studies with $\mathrm{CB}_{1} \mathrm{R}$ chimeras whereby mutagenesis prevents agonistinduced endocytosis and constitutive receptor activation (Hsieh et al., 1999; Roche et al., 1999). Overall, constitutive $\mathrm{CB}_{1} \mathrm{R}$ endocytosis in the somatodendritic compartment appears to be controlled by mechanisms likely involving different motifs/conformational states within the $\mathrm{CB}_{1} \mathrm{R}$ and distinct from those utilized upon agonist-induced internalization. Considering that structural and conformational requirements of constitutive and agonist-induced receptor trafficking are distinct in many other GPCRs (Waldhoer et al., 2003; Whistler et al., 2002), identifying particular structural domains of the $C_{1} R$ that determine subcellular receptor targeting will be pivotal for our better understanding of $\mathrm{CB}_{1} \mathrm{R}$ signaling not only during neurodevelopment but also in many disease conditions in the postnatal brain. Selective axonal targeting of $\mathrm{CB}_{1} \mathrm{Rs}$ from the early period of acquiring neuronal polarity throughout neuronal specification suggests that this conserved mechanism is of key importance with regards to neuronal differentiation and synapse development.

\section{Endocannabinoids shape neuronal connectivity}

The survival of neurochemically-defined sets of neurons requires the correct patterning of axons and the establishment of functional synapses. Accordingly, the concept has recently evolved that eCB signaling through $\mathrm{CB}_{1} \mathrm{Rs}$ controls the initial phase of neurochemical specification and exerts differential effects on growth cone navigation, axonal elongation, and synaptogenesis of inhibitory interneurons and excitatory (pyramidal) cells in the mammalian cerebrum (Berghuis et al., 2004; Berghuis et al., 2005; Berghuis et al., 2007; Mulder et al., 2008). This hypothesis is supported by recent data in chick and zebrafish models showing that $\mathrm{CB}_{1} \mathrm{R}$ expression follows neuronal differentiation from the earliest embryonic stages, and interfering with $\mathrm{CB}_{1} \mathrm{R}$ functions causes profound problems in axonal pathfinding and fasciculation (Watson et al., 2008).

The concept that 'on-demand' eCB signaling links axonal specification in the early embryonic brain to synaptogenesis and synaptic plasticity during the neonatal period is supported by recent evidence identifying eCBs as a class of axon guidance cues as shown in chemotropic and galvanotropic growth cone turning assays in vitro (Berghuis et al., 2007). $A$ unique feature of $C_{B} R$ distribution in the fetal mouse and human brains is its association with several developing axonal trajectories in the white matter. This type of $\mathrm{CB}_{1} \mathrm{R}$ localization, widely considered as 'atypical' receptor positioning (Romero et al., 1997), has recently been identified as a prerequisite of guiding the elongating axons to their targets (Mulder et al., 2008; Watson et al., 2008), and to achieving proper synapse positioning of postsynaptic target cells (Berghuis et al., 2007). The evolving concept of eCB-driven synapse specification is further supported by the removal of $\mathrm{CB}_{1} \mathrm{R}$ from developing axonal tracts coincident with the conclusion of synaptogenesis and the selection of post-synaptic targets (Berghuis et al., 2005; Berghuis et al., 2007; Fernandez-Ruiz et al., 2000), and the selective accumulation of $\mathrm{CB}_{1} \mathrm{Rs}$ in growth cones acquiring structural features of synapses, in particular their capacity of vesicular neurotransmitters release (Berghuis et al., 2007). Additional data show translocation of DAGL expression loci (Bisogno et al., 2003; Mulder et al., 2008) during local navigation and postsynaptic target selection of both local inhibitory afferents and corticothalamic and 
intercallosal pyramidal cell axons during corticogenesis: intrinsic DAGL $\alpha / \beta$ activity within axonal growth cones is sustained throughout axonal navigation, with rapid down-regulation of DAGL $\alpha / \beta$ levels upon postsynaptic target selection and synapse maturation. These changes in the sites of DAGL expression suggest that the specification and extension of axons towards postsynaptic target areas may require autocrine eCB signaling (Bisogno et al., 2003; Williams et al., 2003), while the precise positioning of synapses on postsynaptic targets, the establishment of cell-to-cell contacts, and the onset of synaptic communication within target regions are controlled by the spatially compartmentalized actions of target-derived eCBs (Berghuis et al., 2007; Harkany et al., 2007). Overall, these data support that eCB signaling in the embryonic brain directly translates into retrograde synaptic signaling once synapse establishment concludes.

\section{Conclusions}

Multiple levels of evidence from complementary disciplines of developmental biology, molecular genetics, electrophysiology, neuropharmacology and the neurosciences demonstrate that eCB signaling modulates CNS patterning by tuning the size of neural progenitors pools generating neurons and glia, by defining the sizes of neuronal contingents undergoing radial or tangential migration to populate the developing cerebrum, and by controlling the morphological and functional specification of developing neurons (Fig. 1). Therefore, eCB signaling networks are sufficiently organized to evolve into feedback loops underlying retrograde synaptic transmission when immature neuronal networks become operational. Epidemiological and genetic evidence show that interference with eCB signaling in the developing brain by, e.g., cannabis exposure (Huizink et al., 2006), and genetic (cnr1, faah) variations (Ujike et al., 2002; Weiser et al., 2005), have enduring impact on the establishment of cortical neuronal networks. The diversity of enzymes and receptors contributing to the onset of eCB signaling during brain development clearly requires the continued identification of molecular substrates of eCB synthesis, and degradation, together with defining the cellular context-specific recruitment of second messenger cascades to understand microenvironmental requirements necessary for physiological eCB signaling to occur during brain development. Understanding the temporal and spatial control of specific gene activation patterns regulated by prenatal drug exposure will lead to the characterization of novel, cannabis-sensitive cellular mechanisms controlling particular stages of neuronal development, and will ultimately reveal the neural basis of developmental defects imposed by prenatal cannabis abuse.

\section{Acknowledgements}

This work was supported by grants from the Swedish Medical Research Council (T.H.), Hjärnfonden (Sweden, T.H.), Alzheimer's Association (T.H.), EMBO Young Investigator Programme (T.H.), the Scottish Universities Life Science Alliance (SULSA Cell Biology; T.H.), European Community $7^{\text {th }}$ Framework Programme (HEALTH-F22007-201159; T.H.). K.B. is recipient of a long-term Eötvös Fellowship of the Hungarian Scholarship Board. J.M. is supported by a postdoctoral fellowship from the Alzheimer's Research Trust (UK). 


\section{Legend to Fig. 1}

Neuronal specification is controlled by endocannabinoids (eCBs) acting on $\mathrm{CB}_{1}$ cannabinoid receptors $\left(\mathrm{CB}_{1} \mathrm{Rs}\right.$; green ovals). Solid arrows indicate the likely involvement of target-derived eCB actions in particular specification processes; whereas circular arrows denote probable cell-autonomous mechanisms through intrinsic DAGL expression and regulated eCB release. Question marks point to existing data suggesting the involvement of other cannabinoid-sensing receptors $\left(\mathrm{CB}_{2} \mathrm{R}\right.$, GPR55) during particular steps of neuronal development. 


\section{References}

Abe, H., Yanagawa, Y., Kanbara, K., Maemura, K., Hayasaki, H., Azuma, H., Obata, K., Katsuoka, Y., Yabumoto, M., Watanabe, M., 2005. Epithelial localization of green fluorescent protein-positive cells in epididymis of the GAD67-GFP knock-in mouse. J. Androl 26, 568-577.

Aguado, T., Monory, K., Palazuelos, J., Stella, N., Cravatt, B., Lutz, B., Marsicano, G., Kokaia, Z., Guzman, M., GalveRoperh, I., 2005. The endocannabinoid system drives neural progenitor proliferation. FASEB J. 19, 1704-1706.

Aguado, T., Palazuelos, J., Monory, K., Stella, N., Cravatt, B., Lutz, B., Marsicano, G., Kokaia, Z., Guzman, M., GalveRoperh, I., 2006. The endocannabinoid system promotes astroglial differentiation by acting on neural progenitor cells. J. Neurosci. 26, 1551-1561.

Arevalo-Martin, A., Garcia-Ovejero, D., Rubio-Araiz, A., Gomez, O., Molina-Holgado, F., Molina-Holgado, E., 2007. Cannabinoids modulate Olig2 and polysialylated neural cell adhesion molecule expression in the subventricular zone of post-natal rats through cannabinoid receptor 1 and cannabinoid receptor 2. Eur. J. Neurosci. 26, 1548-1559.

Baker, D., Pryce, G., Davies, W.L., Hiley, C.R., 2006. In silico patent searching reveals a new cannabinoid receptor. Trends Pharmacol. Sci. 27, 1-4.

Berghuis, P., Dobszay, M.B., Ibanez, R.M., Ernfors, P., Harkany, T., 2004. Turning the heterogeneous into homogeneous: studies on selectively isolated GABAergic interneuron subsets. Int. J. Dev. Neurosci. 22, 533-543.

Berghuis, P., Dobszay, M.B., Wang, X., Spano, S., Ledda, F., Sousa, K.M., Schulte, G., Ernfors, P., Mackie, K., Paratcha, G., Hurd, Y.L., Harkany, T., 2005. Endocannabinoids regulate interneuron migration and morphogenesis by transactivating the TrkB receptor. Proc. Natl. Acad. Sci. U. S. A 102, 19115-19120.

Berghuis, P., Rajnicek, A.M., Morozov, Y.M., Ross, R.A., Mulder, J., Urban, G.M., Monory, K., Marsicano, G., Matteoli, M., Canty, A., Irving, A.J., Katona, I., Yanagawa, Y., Rakic, P., Lutz, B., Mackie, K., Harkany, T., 2007. Hardwiring the brain: endocannabinoids shape neuronal connectivity. Science 316, 1212-1216.

Bernard, C., Milh, M., Morozov, Y.M., Ben Ari, Y., Freund, T.F., Gozlan, H., 2005. Altering cannabinoid signaling during development disrupts neuronal activity. Proc. Natl. Acad. Sci. U. S. A 102, 9388-9393.

Berrendero, F., Sepe, N., Ramos, J.A., Di, M., V, Fernandez-Ruiz, J.J., 1999. Analysis of cannabinoid receptor binding and mRNA expression and endogenous cannabinoid contents in the developing rat brain during late gestation and early postnatal period. Synapse 33, 181-191.

Bisogno, T., Howell, F., Williams, G., Minassi, A., Cascio, M.G., Ligresti, A., Matias, I., Schiano-Moriello, A., Paul, P., Williams, E.J., Gangadharan, U., Hobbs, C., Di, M., V, Doherty, P., 2003. Cloning of the first sn1-DAG lipases points to the spatial and temporal regulation of endocannabinoid signaling in the brain. J. Cell Biol. 163, 463-468.

Brown, A.J., 2007. Novel cannabinoid receptors. Br. J. Pharmacol. 152, 567-575.

Coutts, A.A., Anavi-Goffer, S., Ross, R.A., MacEwan, D.J., Mackie, K., Pertwee, R.G., Irving, A.J., 2001. Agonist-induced internalization and trafficking of cannabinoid CB1 receptors in hippocampal neurons. J. Neurosci. 21, 2425-2433.

Cravatt, B.F., Giang, D.K., Mayfield, S.P., Boger, D.L., Lerner, R.A., Gilula, N.B., 1996. Molecular characterization of an enzyme that degrades neuromodulatory fatty-acid amides. Nature 384, 83-87.

D'Antona, A.M., Ahn, K.H., Kendall, D.A., 2006. Mutations of CB1 T210 produce active and inactive receptor forms: correlations with ligand affinity, receptor stability, and cellular localization. Biochemistry 45, 5606-5617.

Daigle, T.L., Kearn, C.S., Mackie, K., 2008. Rapid CB(1) cannabinoid receptor desensitization defines the time course of ERK1/2 MAP kinase signaling. Neuropharmacology 54, 36-44.

Derkinderen, P., Toutant, M., Burgaya, F., Le Bert, M., Siciliano, J.C., de, F., V, Gelman, M., Girault, J.A., 1996. Regulation of a neuronal form of focal adhesion kinase by anandamide. Science 273, 1719-1722.

Derkinderen, P., Valjent, E., Toutant, M., Corvol, J.C., Enslen, H., Ledent, C., Trzaskos, J., Caboche, J., Girault, J.A., 2003. Regulation of extracellular signal-regulated kinase by cannabinoids in hippocampus. J. Neurosci. 23, 2371-2382.

Devi, L.A., 2000. G-protein-coupled receptor dimers in the lime light. Trends Pharmacol. Sci. 21, 324-326.

Dinh, T.P., Carpenter, D., Leslie, F.M., Freund, T.F., Katona, I., Sensi, S.L., Kathuria, S., Piomelli, D., 2002. Brain monoglyceride lipase participating in endocannabinoid inactivation. Proc. Natl. Acad. Sci. U. S. A 99, 10819-10824.

Egertova, M., Simon, G.M., Cravatt, B.F., Elphick, M.R., 2007. Localization of N-acyl phosphatidylethanolamine phospholipase D (NAPE-PLD) expression in mouse brain: A new perspective on $\mathrm{N}$-acylethanolamines as neural signaling molecules. J. Comp Neurol. 506, 604-615.

Ellis, J., Pediani, J.D., Canals, M., Milasta, S., Milligan, G., 2006. Orexin-1 receptor-cannabinoid CB1 receptor heterodimerization results in both ligand-dependent and -independent coordinated alterations of receptor localization and function. J. Biol. Chem. 281, 38812-38824.

Fernandez-Ruiz, J., Berrendero, F., Hernandez, M.L., Ramos, J.A., 2000. The endogenous cannabinoid system and brain development. Trends Neurosci. 23, 14-20.

Galve-Roperh, I., Aguado, T., Palazuelos, J., Guzman, M., 2007. The endocannabinoid system and neurogenesis in health and disease. Neuroscientist. 13, 109-114. 
Galve-Roperh, I., Aguado, T., Rueda, D., Velasco, G., Guzman, M., 2006. Endocannabinoids: a new family of lipid mediators involved in the regulation of neural cell development. Curr. Pharm. Des 12, 2319-2325.

Galve-Roperh, I., Sanchez, C., Cortes, M.L., del Pulgar, T.G., Izquierdo, M., Guzman, M., 2000. Anti-tumoral action of cannabinoids: involvement of sustained ceramide accumulation and extracellular signal-regulated kinase activation. Nat. Med. 6, 313-319.

Ghosh, S., Preet, A., Groopman, J.E., Ganju, R.K., 2006. Cannabinoid receptor CB2 modulates the CXCL12/CXCR4mediated chemotaxis of T lymphocytes. Mol. Immunol. 43, 2169-2179.

Guzman, M., 2003. Cannabinoids: potential anticancer agents. Nat. Rev. Cancer 3, 745-755.

Guzman, M., Sanchez, C., Galve-Roperh, I., 2001. Control of the cell survival/death decision by cannabinoids. J. Mol. Med. $78,613-625$

Guzman, M., Sanchez, C., Galve-Roperh, I., 2002. Cannabinoids and cell fate. Pharmacol. Ther. 95, 175-184.

Harkany, T., Guzman, M., Galve-Roperh, I., Berghuis, P., Devi, L.A., Mackie, K., 2007. The emerging functions of endocannabinoid signaling during CNS development. Trends Pharmacol. Sci. 28, 83-92.

He, J.C., Gomes, I., Nguyen, T., Jayaram, G., Ram, P.T., Devi, L.A., Iyengar, R., 2005. The G alpha(o/i)-coupled cannabinoid receptor-mediated neurite outgrowth involves Rap regulation of Src and Stat3. J. Biol. Chem. 280, 3342633434.

Hsieh, C., Brown, S., Derleth, C., Mackie, K., 1999. Internalization and recycling of the CB1 cannabinoid receptor. J. Neurochem. 73, 493-501.

Huizink, A.C., Mulder, E.J., 2006. Maternal smoking, drinking or cannabis use during pregnancy and neurobehavioral and cognitive functioning in human offspring. Neurosci. Biobehav. Rev. 30, 24-41.

lyengar, R., 2005. Teaching resources. Introduction: Overview of pathways and networks and GPCR signaling. Sci. STKE. 2005, tr4

Jin, K., Xie, L., Kim, S.H., Parmentier-Batteur, S., Sun, Y., Mao, X.O., Childs, J., Greenberg, D.A., 2004. Defective adult neurogenesis in CB1 cannabinoid receptor knockout mice. Mol. Pharmacol. 66, 204-208.

Johns, D.G., Behm, D.J., Walker, D.J., Ao, Z., Shapland, E.M., Daniels, D.A., Riddick, M., Dowell, S., Staton, P.C., Green, P., Shabon, U., Bao, W., Aiyar, N., Yue, T.L., Brown, A.J., Morrison, A.D., Douglas, S.A., 2007. The novel endocannabinoid receptor GPR55 is activated by atypical cannabinoids but does not mediate their vasodilator effects. Br. J. Pharmacol. 152, 825-831.

Jordan, J.D., He, J.C., Eungdamrong, N.J., Gomes, I., Ali, W., Nguyen, T., Bivona, T.G., Philips, M.R., Devi, L.A., lyengar, R., 2005. Cannabinoid receptor-induced neurite outgrowth is mediated by Rap1 activation through G(alpha)o/i-triggered proteasomal degradation of Rap1GAPII. J. Biol. Chem. 280, 11413-11421.

Katona, I., Urban, G.M., Wallace, M., Ledent, C., Jung, K.M., Piomelli, D., Mackie, K., Freund, T.F., 2006. Molecular composition of the endocannabinoid system at glutamatergic synapses. J. Neurosci. 26, 5628-5637.

Kreitzer, A.C., Regehr, W.G., 2001. Retrograde inhibition of presynaptic calcium influx by endogenous cannabinoids at excitatory synapses onto Purkinje cells. Neuron 29, 717-727.

Kurihara, R., Tohyama, Y., Matsusaka, S., Naruse, H., Kinoshita, E., Tsujioka, T., Katsumata, Y., Yamamura, H., 2006. Effects of peripheral cannabinoid receptor ligands on motility and polarization in neutrophil-like HL60 cells and human neutrophils. J. Biol. Chem. 281, 12908-12918.

Lauckner, J.E., Hille, B., Mackie, K., 2005. The cannabinoid agonist WIN55,212-2 increases intracellular calcium via CB1 receptor coupling to $\mathrm{Gq} / 11 \mathrm{G}$ proteins. Proc. Natl. Acad. Sci. U. S. A 102, 19144-19149.

Lauckner, J.E., Jensen, J.B., Chen, H.Y., Lu, H.C., Hille, B., Mackie, K., 2008. GPR55 is a cannabinoid receptor that increases intracellular calcium and inhibits M current. Proc. Natl. Acad. Sci. U. S. A

Leterrier, C., Bonnard, D., Carrel, D., Rossier, J., Lenkei, Z., 2004. Constitutive endocytic cycle of the CB1 cannabinoid receptor. J. Biol. Chem. 279, 36013-36021.

Leterrier, C., Laine, J., Darmon, M., Boudin, H., Rossier, J., Lenkei, Z., 2006. Constitutive activation drives compartmentselective endocytosis and axonal targeting of type 1 cannabinoid receptors. J. Neurosci. 26, 3141-3153.

Liu, J., Wang, L., Harvey-White, J., Osei-Hyiaman, D., Razdan, R., Gong, Q., Chan, A.C., Zhou, Z., Huang, B.X., Kim, H.Y., Kunos, G., 2006. A biosynthetic pathway for anandamide. Proc. Natl. Acad. Sci. U. S. A 103, 13345-13350.

Lutz, B., 2004. On-demand activation of the endocannabinoid system in the control of neuronal excitability and epileptiform seizures. Biochem. Pharmacol. 68, 1691-1698.

Maccarrone, M., Rossi, S., Bari, M., De, C., V, Fezza, F., Musella, A., Gasperi, V., Prosperetti, C., Bernardi, G., Finazzi-Agro, A., Cravatt, B.F., Centonze, D., 2008. Anandamide inhibits metabolism and physiological actions of 2-arachidonoylglycerol in the striatum. Nat. Neurosci. 11, 152-159.

Mackie, K., Stella, N., 2006. Cannabinoid receptors and endocannabinoids: evidence for new players. AAPS. J. 8, E298E306.

Maione, S., Bisogno, T., de, N., V, Palazzo, E., Cristino, L., Valenti, M., Petrosino, S., Guglielmotti, V., Rossi, F., Di, M., V, 2006. Elevation of endocannabinoid levels in the ventrolateral periaqueductal grey through inhibition of fatty acid amide 
hydrolase affects descending nociceptive pathways via both cannabinoid receptor type 1 and transient receptor potential vanilloid type-1 receptors. J. Pharmacol. Exp. Ther. 316, 969-982.

Matias, I., Di Marzo, V., 2006. Endocannabinoid synthesis and degradation, and their regulation in the framework of energy balance. J. Endocrinol. Invest 29, 15-26.

Mato, S., Del Olmo, E., Pazos, A., 2003. Ontogenetic development of cannabinoid receptor expression and signal transduction functionality in the human brain. Eur. J. Neurosci. 17, 1747-1754.

Matyas, F., Urban, G.M., Watanabe, M., Mackie, K., Zimmer, A., Freund, T.F., Katona, I., 2008. Identification of the sites of 2-arachidonoylglycerol synthesis and action imply retrograde endocannabinoid signaling at both GABAergic and glutamatergic synapses in the ventral tegmental area. Neuropharmacology 54, 95-107.

McDonald, N.A., Henstridge, C.M., Connolly, C.N., Irving, A.J., 2007a. An essential role for constitutive endocytosis, but not activity, in the axonal targeting of the CB1 cannabinoid receptor. Mol. Pharmacol. 71, 976-984.

McDonald, N.A., Henstridge, C.M., Connolly, C.N., Irving, A.J., 2007b. Generation and functional characterization of fluorescent, N-terminally tagged $\mathrm{CB}(1)$ receptor chimeras for live-cell imaging. Mol. Cell Neurosci. 35, 237-248.

McHugh, D., Tanner, C., Mechoulam, R., Pertwee, R.G., Ross, R.A., 2007. Inhibition of human neutrophil chemotaxis by endogenous cannabinoids and phytocannabinoids: evidence for a site distinct from CB1 and CB2. Mol. Pharmacol.

Mereu, G., Fa, M., Ferraro, L., Cagiano, R., Antonelli, T., Tattoli, M., Ghiglieri, V., Tanganelli, S., Gessa, G.L., Cuomo, V., 2003. Prenatal exposure to a cannabinoid agonist produces memory deficits linked to dysfunction in hippocampal long-term potentiation and glutamate release. Proc. Natl. Acad. Sci. U. S. A 100, 4915-4920.

Miller, A.M., Stella, N., 2007. CB(2) receptor-mediated migration of immune cells: it can go either way. Br. J. Pharmacol.

Molina-Holgado, E., Vela, J.M., Arevalo-Martin, A., Almazan, G., Molina-Holgado, F., Borrell, J., Guaza, C., 2002. Cannabinoids promote oligodendrocyte progenitor survival: involvement of cannabinoid receptors and phosphatidylinositol-3 kinase/Akt signaling. J. Neurosci. 22, 9742-9753.

Molina-Holgado, F., Rubio-Araiz, A., Garcia-Ovejero, D., Williams, R.J., Moore, J.D., Arevalo-Martin, A., Gomez-Torres, O., Molina-Holgado, E., 2007. CB2 cannabinoid receptors promote mouse neural stem cell proliferation. Eur. J. Neurosci. 25, 629-634.

Morishita, J., Okamoto, Y., Tsuboi, K., Ueno, M., Sakamoto, H., Maekawa, N., Ueda, N., 2005. Regional distribution and age-dependent expression of $\mathrm{N}$-acylphosphatidylethanolamine-hydrolyzing phospholipase $\mathrm{D}$ in rat brain. J Neurochem. 94 , 753-762.

Morozov, Y.M., Ben Ari, Y., Freund, T.F., 2004. The spatial and temporal pattern of fatty acid amide hydrolase expression in rat hippocampus during postnatal development. Eur. J Neurosci. 20, 459-466.

Muccioli, G.G., Xu, C., Odah, E., Cudaback, E., Cisneros, J.A., Lambert, D.M., Lopez Rodriguez, M.L., Bajjalieh, S., Stella, N., 2007. Identification of a novel endocannabinoid-hydrolyzing enzyme expressed by microglial cells. J Neurosci. 27, 28832889.

Mulder, A.M., Cravatt, B.F., 2006. Endocannabinoid metabolism in the absence of fatty acid amide hydrolase (FAAH): discovery of phosphorylcholine derivatives of N-acyl ethanolamines. Biochemistry 45, 11267-11277.

Mulder, J., Auguado, T., Barabas, K., Keimpema, E., Ballester Rosado, C.J., Nguyen, L., Monory, K., Marsicano, G., Di Marzo, V., Hurd, Y.L., Guillemot, F., Mackie, K., Lutz, B., Guzman, M., Lu, H.C., Galve-Roperh, I., Harkany, T., 2008. Endocannabinoid signaling is indispensable for pyramidal cell specification and long-range axon patterning. Proc Natl. Acad. Sci. U. S. A submitted.

Munro, S., Thomas, K.L., Abu-Shaar, M., 1993. Molecular characterization of a peripheral receptor for cannabinoids. Nature $365,61-65$.

Niehaus, J.L., Liu, Y., Wallis, K.T., Egertova, M., Bhartur, S.G., Mukhopadhyay, S., Shi, S., He, H., Selley, D.E., Howlett, A.C., Elphick, M.R., Lewis, D.L., 2007. CB1 cannabinoid receptor activity is modulated by the cannabinoid receptor interacting protein CRIP 1a. Mol. Pharmacol. 72, 1557-1566.

Ohno-Shosaku, T., Tsubokawa, H., Mizushima, I., Yoneda, N., Zimmer, A., Kano, M., 2002. Presynaptic cannabinoid sensitivity is a major determinant of depolarization-induced retrograde suppression at hippocampal synapses. J. Neurosci. 22, 3864-3872.

Oka, S., Nakajima, K., Yamashita, A., Kishimoto, S., Sugiura, T., 2007. Identification of GPR55 as a lysophosphatidylinositol receptor. Biochem. Biophys. Res. Commun. 362, 928-934.

Okamoto, Y., Wang, J., Morishita, J., Ueda, N., 2007. Biosynthetic pathways of the endocannabinoid anandamide. Chem. Biodivers. 4, 1842-1857.

Piomelli, D., 2003. The molecular logic of endocannabinoid signalling. Nat. Rev. Neurosci. 4, 873-884.

Preet, A., Ganju, R.K., Groopman, J.E., 2007. Delta(9)-Tetrahydrocannabinol inhibits epithelial growth factor-induced lung cancer cell migration in vitro as well as its growth and metastasis in vivo. Oncogene

Rajesh, M., Mukhopadhyay, P., Hasko, G., Huffman, J.W., Mackie, K., Pacher, P., 2007. CB(2) cannabinoid receptor agonists attenuate TNF-alpha-induced human vascular smooth muscle cell proliferation and migration. Br. J. Pharmacol.

Rimmerman, N., Hughes, H.V., Bradshaw, H.B., Pazos, M.X., Mackie, K., Prieto, A.L., Walker, J.M., 2008. Compartmentalization of endocannabinoids into lipid rafts in a dorsal root ganglion cell line. Br. J. Pharmacol. 153, 380-389. 
Rinaldi-Carmona, M., Le Duigou, A., Oustric, D., Barth, F., Bouaboula, M., Carayon, P., Casellas, P., Le Fur, G., 1998. Modulation of CB1 cannabinoid receptor functions after a long-term exposure to agonist or inverse agonist in the Chinese hamster ovary cell expression system. J. Pharmacol. Exp. Ther. 287, 1038-1047.

Rios, C., Gomes, I., Devi, L.A., 2006. mu opioid and CB1 cannabinoid receptor interactions: reciprocal inhibition of receptor signaling and neuritogenesis. Br. J. Pharmacol. 148, 387-395.

Roche, J.P., Bounds, S., Brown, S., Mackie, K., 1999. A mutation in the second transmembrane region of the CB1 receptor selectively disrupts $G$ protein signaling and prevents receptor internalization. Mol. Pharmacol. 56, 611-618.

Romero, J., Garcia-Palomero, E., Berrendero, F., Garcia-Gil, L., Hernandez, M.L., Ramos, J.A., Fernandez-Ruiz, J.J., 1997. Atypical location of cannabinoid receptors in white matter areas during rat brain development. Synapse 26, 317-323.

Rueda, D., Navarro, B., Martinez-Serrano, A., Guzman, M., Galve-Roperh, I., 2002. The endocannabinoid anandamide inhibits neuronal progenitor cell differentiation through attenuation of the Rap1/B-Raf/ERK pathway. J. Biol. Chem. 277, 46645-46650.

Ryberg, E., Larsson, N., Sjogren, S., Hjorth, S., Hermansson, N.O., Leonova, J., Elebring, T., Nilsson, K., Drmota, T., Greasley, P.J., 2007. The orphan receptor GPR55 is a novel cannabinoid receptor. Br. J. Pharmacol. 152, 1092-1101.

Ryberg, E., Vu, H.K., Larsson, N., Groblewski, T., Hjorth, S., Elebring, T., Sjogren, S., Greasley, P.J., 2005. Identification and characterisation of a novel splice variant of the human CB1 receptor. FEBS Lett. 579, 259-264.

Sampo, B., Kaech, S., Kunz, S., Banker, G., 2003. Two distinct mechanisms target membrane proteins to the axonal surface. Neuron 37, 611-624.

Sawzdargo, M., Nguyen, T., Lee, D.K., Lynch, K.R., Cheng, R., Heng, H.H., George, S.R., O'Dowd, B.F., 1999. Identification and cloning of three novel human $G$ protein-coupled receptor genes GPR52, PsiGPR53 and GPR55: GPR55 is extensively expressed in human brain. Brain Res. Mol. Brain Res. 64, 193-198.

Seong, E., Wainer, B.H., Hughes, E.D., Saunders, T.L., Burmeister, M., Faundez, V., 2005. Genetic analysis of the neuronal and ubiquitous AP-3 adaptor complexes reveals divergent functions in brain. Mol. Biol. Cell 16, 128-140.

Simon, G.M., Cravatt, B.F., 2006. Endocannabinoid biosynthesis proceeding through glycerophospho-N-acyl ethanolamine and a role for \{alpha\}/beta-hydrolase 4 in this pathway. J. Biol. Chem. 281, 26465-26472.

Song, Z.H., Zhong, M., 2000. CB1 cannabinoid receptor-mediated cell migration. J. Pharmacol. Exp. Ther. 294, 204-209.

Stoddart, L.A., Brown, A.J., Milligan, G., 2007. Uncovering the pharmacology of the G protein-coupled receptor GPR40: high apparent constitutive activity in guanosine 5'-O-(3-[35S]thio)triphosphate binding studies reflects binding of an endogenous agonist. Mol. Pharmacol. 71, 994-1005.

Turu, G., Simon, A., Gyombolai, P., Szidonya, L., Bagdy, G., Lenkei, Z., Hunyady, L., 2007. The role of diacylglycerol lipase in constitutive and angiotensin AT1 receptor-stimulated cannabinoid CB1 receptor activity. J. Biol. Chem. 282, 7753-7757.

Uchigashima, M., Narushima, M., Fukaya, M., Katona, I., Kano, M., Watanabe, M., 2007. Subcellular arrangement of molecules for 2-arachidonoyl-glycerol-mediated retrograde signaling and its physiological contribution to synaptic modulation in the striatum. J Neurosci. 27, 3663-3676.

Ueda, N., Okamoto, Y., Morishita, J., 2005. N-acylphosphatidylethanolamine-hydrolyzing phospholipase D: a novel enzyme of the beta-lactamase fold family releasing anandamide and other $\mathrm{N}$-acylethanolamines. Life Sci. 77, 1750-1758.

Ujike, H., Takaki, M., Nakata, K., Tanaka, Y., Takeda, T., Kodama, M., Fujiwara, Y., Sakai, A., Kuroda, S., 2002. CNR1, central cannabinoid receptor gene, associated with susceptibility to hebephrenic schizophrenia. Mol. Psychiatry 7, 515-518.

van der Stelt, M., Di Marzo, V., 2005. Anandamide as an intracellular messenger regulating ion channel activity. Prostaglandins Other Lipid Mediat. 77, 111-122.

Wager-Miller, J., Westenbroek, R., Mackie, K., 2002. Dimerization of G protein-coupled receptors: CB1 cannabinoid receptors as an example. Chem. Phys. Lipids 121, 83-89.

Waldhoer, M., Casarosa, P., Rosenkilde, M.M., Smit, M.J., Leurs, R., Whistler, J.L., Schwartz, T.W., 2003. The carboxyl terminus of human cytomegalovirus-encoded 7 transmembrane receptor US28 camouflages agonism by mediating constitutive endocytosis. J. Biol. Chem. 278, 19473-19482.

Walter, L., Franklin, A., Witting, A., Wade, C., Xie, Y., Kunos, G., Mackie, K., Stella, N., 2003. Nonpsychotropic cannabinoid receptors regulate microglial cell migration. J. Neurosci. 23, 1398-1405.

Wang, X., Dow-Edwards, D., Keller, E., Hurd, Y.L., 2003. Preferential limbic expression of the cannabinoid receptor mRNA in the human fetal brain. Neuroscience 118, 681-694.

Watson, S., Chambers, D., Hobbs, C., Doherty, P., Graham, A., 2008. The cannabinoid receptor, CB1, is required for normal axonal growth and fasciculation. Mol. Cell Neurosci. in press,

Wei, B.Q., Mikkelsen, T.S., McKinney, M.K., Lander, E.S., Cravatt, B.F., 2006. A second fatty acid amide hydrolase with variable distribution among placental mammals. J. Biol. Chem. 281, 36569-36578.

Weiser, M., Noy, S., 2005. Interpreting the association between cannabis use and increased risk for schizophrenia. Dialogues. Clin. Neurosci. 7, 81-85.

Whistler, J.L., Gerber, B.O., Meng, E.C., Baranski, T.J., von Zastrow, M., Bourne, H.R., 2002. Constitutive activation and endocytosis of the complement factor 5a receptor: evidence for multiple activated conformations of a $\mathrm{G}$ protein-coupled receptor. Traffic. 3, 866-877. 
Williams, E.J., Walsh, F.S., Doherty, P., 2003. The FGF receptor uses the endocannabinoid signaling system to couple to an axonal growth response. J. Cell Biol. 160, 481-486.

Wilson, R.I., Kunos, G., Nicoll, R.A., 2001a. Presynaptic specificity of endocannabinoid signaling in the hippocampus. Neuron 31, 453-462.

Wilson, R.I., Nicoll, R.A., 2001b. Endogenous cannabinoids mediate retrograde signalling at hippocampal synapses. Nature 410, 588-592.

Wisco, D., Anderson, E.D., Chang, M.C., Norden, C., Boiko, T., Folsch, H., Winckler, B., 2003. Uncovering multiple axonal targeting pathways in hippocampal neurons. J. Cell Biol. 162, 1317-1328. 
Harkany et al., Fig. 1

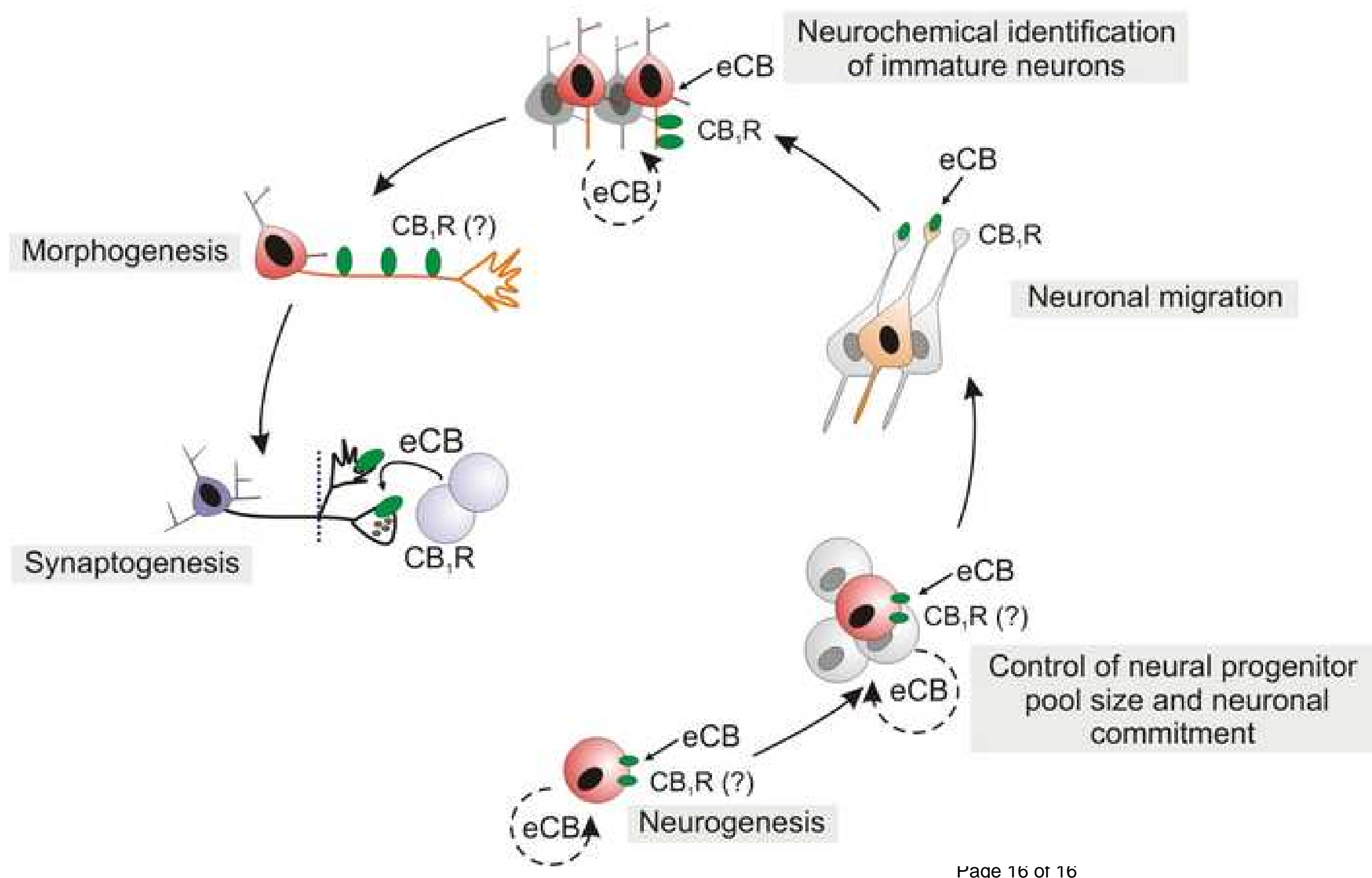

